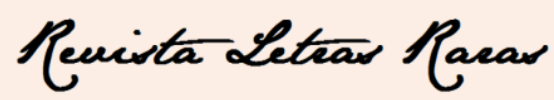

ISSN: 2317-2347 - Vol. 5, Ano 5, № 2 - 2016

\title{
Formulações estéticas e culturais do romance Terra Sonâmbula, de Mia Couto
}

\author{
José Augusto Soares Lima* \\ Maria Marta dos Santos S. Nóbrega ${ }^{* *}$
}

\begin{abstract}
Resumo: As narrativas africanas estão associadas às múltiplas influências que se arrastam de um passado colonial atravessado pela dominação europeia até um presente em que a tradição e a modernidade se entrecruzam na construção de formas narrativas como reação às subserviências instaladas desde séculos atrás. Terra sonâmbula é essa expressão romanesca que se vincula à redefinição das identidades, assimilando as tradições da oratura africana, acomodando os enredos dos contos que inscrevem as vozes os antigos griots na escritura, remodelando-a. A palavra torna-se signo de ambivalência em que por meio dela estão calcadas as viagens (deslocamentos físicos e mergulhos nos enredos das narrativas orais) empreendidas por Tuahir e por Muidinga. Este artigo envereda pelos domínios do romance moçambicano, buscando investigar as dobras da escritura potencializada pela oratura a ela associada. Os principais objetivos: 1) Caracterizar a questão genológica da narrativa em estudo e suas relações com as narrativas orais africanas; e 2) Investigar os aspectos estético-literários que envolvem a palavra escrita, que evidenciam as inscrições culturais africanas, ao reverberar e assimilar as dicções da tradição oral africana. A partir disso, o estudo das escrituras africanas revela a função bárdica e as dimensões performática e estética que potencializam a palavra escrita amalgamada ao encantamento que se insinua para o leitor, desmantelando os padrões genológicos estabelecidos pelo cânone europeu excludente. Nossas reflexões estão fundamentadas à luz das teorias de Leite (2012; 2013); Zumthor (2014); Krakowska (2012); entre outros.
\end{abstract}

Palavras-chave: Aspectos Estéticos. Performance. Oratura. Literatura africana.

\section{Aesthetic and cultural formulations of romance Terra}

\section{Sonâmbula of Mia Couto}

\begin{abstract}
African narratives are associated with the multiple influences that drift from a colonial past traversed by European domination to a present which tradition and modernity intersect in the construction of narrative forms as reaction to the subservience established centuries ago. Terra sonâmbula is a romanesque expression that is linked to the redefinition of identities, assimilating the traditions of African origin, accommodating the entanglements of the tales that inscribe the voices of the ancient griots in the writing, reshaping it. The word becomes a sign of ambivalence in which the travels (physical displacements and dives into the plots of the oral narratives) undertaken by Tuahir and Muidinga are based. This article goes through the domains of the Mozambican novel, seeking to investigate the ways of the writing enhanced by orality set associeted. The main objectives are: 1) To characterize the genre issue of the narrative under study and its relations with African oral narratives; And 2) To investigate the aesthetic-literary aspects that involve the written word, that evidences the African cultural inscriptions, to make clear and assimilate the dictions of the African oral tradition. From this, the study of the African scriptures reveals the bardic function and the performatic and aesthetic dimensions that potentiate the written word amalgamated to the enchantment that insinuates itself to the reader, dismantling genetic standards established by the European excluding canon. Our reflections are based on theories of Leite (2012; 2013); Zumthor (2014); Krakowska (2012); among others.
\end{abstract}

\footnotetext{
* Mestre em Linguagem e Ensino, pela Universidade Federal de Campina Grande (2016). Professor de Literatura Brasileira da Rede Privada de ensino. Contato: augustolima20@ gmail.com.

* *Doutora em Teoria e História Literária pela Universidade Estadual de Campinas. Professora da Graduação em Letras e da Pós-Graduação em Linguagem e Ensino da Universidade Federal de Campina Grande. Contato: mariamartanobrega@bol.com.br.
}

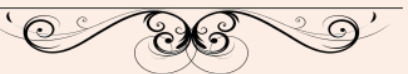




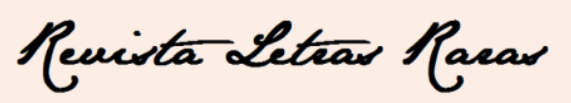

ISSN: 2317-2347 - Vol. 5, Ano 5, № 2 - 2016

Keywords: Aesthetic Aspects. Performance. Orature. African Literature.

"Não é a estória que fascina mas a alma que está nela."

Mia Couto

\section{Introdução}

Devastação e desesperança são características que permeiam o cenário de Terra sonâmbula (2007), obra do moçambicano Mia Couto, publicada pela primeira vez em 1992. Romance inaugural do autor no gênero, Terra sonâmbula está permeado por um fio que cerze os mitos das narrativas orais africanas, transformando-as em um enredo multifacetado e evidenciando em cada um o olhar poético de onde emanam as sensibilidades despertadas por imagens profundas do cotidiano destruído e aterrorizado pelos conflitos bélicos instalados no território nacional. "A guerra é uma cobra que usa nossos próprios dentes para nos morder." (COUTO, 2007, p.17)

Dotada de forte lirismo, a linguagem da obra ganha contornos poéticos que inserem as personagens numa perspectiva subjetivada pela situação limítrofe da nação devastada pela guerra, interferindo substancialmente na condição dos indivíduos. Nesse sentido, a elocução das vozes narrativas que singularizam o romance permite uma percepção performática ${ }^{1}$ da palavra escrita que ganha feições da oralidade.

A experiência humana, desafiada pelo olhar que capta a destruição e a morte que se alastram por toda parte, em meio ao contexto de guerra, é o grande motivo da narrativa que se debruça sobre os caminhos traçados por Tuahir e Muidinga. "Aqui, o céu se tornara impossível. E os viventes se acostumaram ao chão, em resignada aprendizagem da morte." (COUTO, 2007, p.9)

Terra sonâmbula é um romance baseado numa gama de aspectos que fornecem ao leitor as significações presentes nos espaços narrativos africanos que acomodam o intervalo, ora tênue, ora profundo, entre ficção e realidade, entre imaginário cultural e experiência vivida no cotidiano.

$\mathrm{O}$ artigo que se descortina se propõem a discutir alguns desses aspectos temáticoestruturais que viabilizam, do nosso ponto de vista, algumas interpretações em torno da obra, considerando sua legitimidade na representação cultural moçambicana. Dentre tantos

\footnotetext{
${ }^{1}$ Entendemos “performance” aqui à luz das teorias de Paul Zumthor (2014).
} 


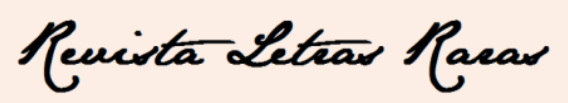

ISSN: 2317-2347 - Vol. 5, Ano 5, № 2 - 2016

aspectos, centramo-nos nas reflexões sobre a dimensão que a narrativa coutiana ganha ao agregar ao gênero romance aspectos das narrativas orais, dos mitos e das crenças que singularizam e encorpam a trama narrativa.

Além de tais questões, associando às histórias e experiências que cruzam o percurso do velho e do menino, a engenhosidade e a poeticidade da linguagem como elementos de relevo no romance por permitirem a difusão de vozes, tornando-as efusivas nas micronarrativas que compõem os dois "arquienredos" de Terra sonâmbula.

Dessa forma, traçamos como principais objetivos para nossas considerações: 1) Caracterizar a questão genológica da narrativa em estudo e suas relações com as narrativas orais africanas; e 2) Investigar os aspectos estético-literários que envolvem a palavra escrita, que evidenciam as inscrições culturais africanas, ao reverberar e assimilar as dicções da tradição oral africana.

\section{A questão genológica do romance moçambicano}

A constituição do gênero romance na pós-modernidade corresponde aos hibridismos que resultam das propostas contemporâneas de fragmentação dos padrões e referências estabelecidos no contexto social. A cada experiência estética são inauguradas novas identidades romanescas, implodindo padrões, erigindo formas que não correspondem a cânones teóricos e críticos.

As formulações das narrativas africanas estão profundamente associadas aos diversos contextos culturais em que o passado e o presente, a tradição e a modernidade se entrecruzam na constituição da representação literária. O romance de Mia Couto ganha notoriedade nos estudos das narrativas africanas lusófonas devido às dimensões atribuídas à palavra, configurando-a como fonte de poeticidade, como já expresso no início deste artigo.

Terra sonâmbula é essa expressão romanesca que se vincula à redefinição das identidades, assimilando as tradições orais africanas, acomodando os enredos dos contos, configurando-se uma narrativa múltipla e diversa na constituição de uma identidade para o romance.

Os "arquienredos" da obra coutiana em estudo, assim caracterizados por acomodarem em suas tramas enredos menores (não na relevância, mas na constituição 


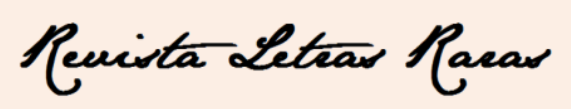

ISSN: 2317-2347 - Vol. 5, Ano 5, № 2 - 2016

estrutural) das narrativas orais de África, são trajetos de viagens empreendidos pelos personagens Tuahir, Muidinga e Kindzu que se revelam alternadamente e que indicam o entrelaçamento das tramas em que ambas se complementam.

Muidinga e Tuahir saem do "campo de deslocados" na busca pela sobrevivência em meio à guerra. Nesse sentido, ao buscarem abrigo, passam a caminhar desolados em meio à destruição refletida nos espaços com que se deparam. "A estrada que agora se abre a nossos olhos não se entrecruza com outra nenhuma. Está mais deitada que os séculos, suportando sozinha toda a distância.” (COUTO, 2007, p.9)

Na busca por refúgio, encontram não uma permanência, mas outras vias. Os cadernos de Kindzu são encontrados e abrem acessos, já traçados, nos mesmos lugares. São memórias de um viajante que se lança na estrada em busca da conquista de outros espaços. $\mathrm{O}$ compartilhamento dessas memórias por meio da leitura de Muidinga passa a configurar outras viagens, agora, as aventuras que fazem o morto reviver com uma importância ancestral, correspondendo à sabedoria cultivada pela cultura local. "Acendo a estória, me apago a mim. No fim destes escritos, serei de novo uma sombra sem voz.” (COUTO, 2007, p.15)

Por essa formulação dupla, Terra sonâmbula se insere na construção de um romance em que a percepção rarefeita da realidade moçambicana frente à guerra está amalgamada aos enfrentamentos culturais. A tradição e a modernidade compõem as experiências subjetivas das personagens, movendo as fronteiras, inaugurando identidades complexas e multifacetadas que estão longe da fixidez dos padrões estabelecidos durante séculos. Nesse contexto, Tuahir e Muidinga seguem o destino que a estrada conduz, enquanto param todas as noites para descansar e se aninharem nos enredos de Kindzu.

As identidades culturais na pós-modernidade são múltiplas e descentradas de um modelo rígido e bem delimitado (HALL, 2014). Nesse sentido, o estabelecimento e a permanência de um gênero literário não ocorrem de maneira imediata. São diversas as discussões e as polêmicas acerca dos paradigmas existentes em torno da teoria dos gêneros literários, que partem desde a Antiguidade Clássica, com os pensamentos de Platão, até a Teoria Literária atual.

Os estudos literários contemporâneos reconfiguram as categorias genológicas, considerando o dinamismo da atualidade, o movimento constante de construção e desconstrução das identidades. A partir disso, a concepção dinâmica, histórica e sociológica 


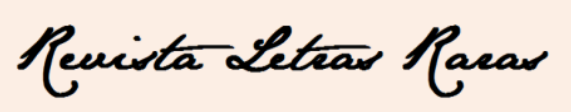

ISSN: 2317-2347 - Vol. 5, Ano 5, № 2 - 2016

dos gêneros, segundo Aguiar e Silva (2011), ao discutir uma visão biologista ${ }^{2}$, afirma que eles vivem e desenvolvem-se, podendo modificar-se lentamente, mas também sofrer bruscas e radicais mutações.

Por esse mesmo ponto de vista, Aguiar e Silva (2011), ao se referir aos formalistas russos, afirma:

Rejeitando qualquer dogmatismo reducionista que originaria uma classificação rígida e estática, os formalistas russos conceberam o gênero literário como uma entidade evolutiva, cujas transformações adquirem sentido no quadro geral do sistema literário e na correlação deste sistema com as mudanças operadas no sistema social, e por isso advogaram uma classificação historicamente descritiva dos gêneros. (AGUIAR E SILVA, 2011, p.371)

Adentrando pelos domínios das Literaturas africanas de Língua Portuguesa, podemos destacar que a remodelação dos gêneros, em específico na ficção narrativa, é reflexo das influências da pós-modernidade nas sociedades pós-coloniais, no continente estabelecidas. A redefinição das fronteiras relativizou a constituição dos gêneros da tradição em veiculadores dos aspectos socioculturais da atualidade, sem abandonar o passado ainda vigente pela oratura.

As narrativas africanas estão associadas às múltiplas influências que se arrastam de um passado colonial atravessado pela dominação europeia até um presente em que, como já dito, a tradição e a modernidade se enlaçam na construção de uma nova estrutura narrativa como reação às subserviências instaladas desde séculos atrás.

As direções assinaladas pela elaboração da identidade ficcional das nações africanas, que associa a tradição à modernidade, indicam uma perspectiva em que os gêneros se imbricam e se reformulam, subvertendo os estudos da Teoria literária acerca da delimitação das fronteiras entre os gêneros.

A presença da oralidade na literatura africana aponta para a consideração da narrativa como lugar de encontro das múltiplas possibilidades que os sistemas culturais podem acomodar em suas expressões. As diversas influências dessas alternativas permitem a criação de uma subjetividade que perpassa a obra africana, subvertendo qualquer padrão estabelecido nos estudos genológicos tradicionais.

\footnotetext{
${ }^{2}$ Aguiar e Silva (2011) atribui essa perspectiva à Teoria da literatura de Boris Tomasevskij (1978).
} 


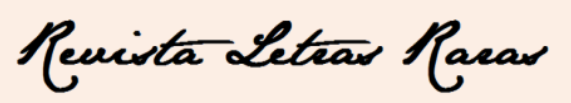

ISSN: 2317-2347 - Vol. 5, Ano 5, № 2 - 2016

Acerca dessas questões, Ana Mafalda Leite (2012) afirma que

O texto literário deve ser olhado já não como um espelho reprodutor dos elementos culturais, mas, antes, como um campo prismático de interação entre discursos culturais e literários. A essa luz pode descrever-se a literatura como um processo de mediação sobre a cultura. As configurações entre oralidade e escrita, em cada obra, e cada literatura africana, ganham, assim, as diferenças necessárias. (LEITE, 2012, p.166)

A dimensão que o texto ficcional africano alcança, potencializa a fluidez entre os gêneros de diferentes modalidades (oral/escrita), tornando híbrida a configuração da narrativa romanesca. Por esse olhar, os gêneros orais perpassam os gêneros escritos, no nosso caso, o romance, para transfigurar a fixidez da categorização dos gêneros escritos em uma expressão em que se cruzam e se interpenetram a diversidade de aspectos culturais.

Além disso, Leite (2012) destaca que o estudo dos gêneros literários, que considera a representação da oratura africana nos textos literários, sugere a "caracterização de uma textualidade formal manifesta que se observa pela detecção de técnicas narrativas características" (LEITE, 2012, p.166) [grifo do autor] em que expressões advindas da oralidade e os próprios gêneros orais tornam-se fórmulas dessa identidade narrativa escrita.

Nesse sentido, a consideração de uma textualidade não manifesta também é capaz de nos revelar "sentidos culturais subjacentes a essa representação, enquanto configuração simbólica de diferentes modos de mundividência e de encarar o ato criativo." (LEITE, 2012, p.167). A estrutura literária é transportadora dos enfrentamentos em que está alicerçada a narrativa moçambicana que acomoda essa multiplicidade de narrativas e as assimila na construção de um "arquienredo" cheio de dobras simbólicas que garantem a sobrevivência dos gêneros orais no romance moderno.

Se, por um lado, a narrativa coutiana ganha identidade e formato na profusão que a linguagem escrita acrescenta às lendas, aos contos, às expressões e aos provérbios em contexto escrito, por outro lado, as narrativas orais reconduzem a escrita às origens que a palavra possuía enquanto instrumento de performance frente a um público expectador. Desse movimento de fronteiras entre o oral e o escrito, entre a tradição e a modernidade nasce a expressão escrita das narrativas de Mia Couto singularizada ao tentar se "naturalizar" por permitir o mergulho do leitor no que há de mais original da cultura africana: ser ouvinte dos enredos de griots da modernidade. 


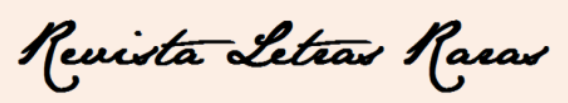

ISSN: 2317-2347 - Vol. 5, Ano 5, № 2 - 2016

Em Terra sonâmbula, essa expressão literária limítrofe descamba para a subversão das categorizações narrativas, redesenhando no romance a consciência de uma oratura de qualidade que não deve ser desconsiderada como elemento cultural. À luz dessa percepção, as influências da tradição oral reconfiguram os gêneros, sobrepondo aspectos intrínsecos a cada conto, provérbio e expressão utilizados como espelho das manifestações culturais próprias da nação moçambicana.

A estrutura dialógica do romance evidencia as convicções de uma criação narrativa que surge pelas vozes, que emanam da tradição, amalgamadas às estruturas narrativas modernas. Os enredos se alternam e se entrelaçam formando uma estrutura dialógica em que se imbricam e culminam num desfecho simbólico de descoberta da identidade subjetiva de Muidinga: Gaspar, o filho perdido de Farida.

Esse processo de alternância de narradores dos enredos maiores singulariza as múltiplas narrativas que se vinculam às personagens e à sequência de episódios. Muidinga e Tuahir fogem da devastação da guerra e se embrenham pela estrada, alojando-se num machimbombo incendiado. As duas personagens se deparam com os cadernos de Kindzu e passam a ler diariamente, após as andanças diárias. As histórias de Kindzu surgem das leituras realizadas pelos personagens do primeiro enredo.

O processo de alternância e de justaposição das duas macronarrativas permite singularizar, na maioria das vezes, cada capítulo como uma unidade fabular independente, episódio que se continua acrescentado de outro episódio-conto. O romance é organizado como uma sequência de contos, ligados por coordenação e, simultaneamente, por encaixe. No final do romance, a primeira narrativa conflui na segunda, e a narrativa imaginária dos cadernos integra-se na primeira história. (LEITE, 2012, p.170)

Assim como em Terra sonâmbula, outros romances de Mia Couto apresentam essa mesma estrutura dialógica. Em O outro pé da sereia (2006), a alternância do tempo é um exemplo em que o câmbio da voz narrativa se estabelece entre narradores que se localizam cronologicamente em anos distintos: um em 2002 e o outro em 1560.

A construção dúplice dos enredos que se interpenetram em pontos específicos da história permite-nos o contato com a produtividade das interseções entre a oratura e a literatura. O mergulho na alternância de vozes narrativas permite-nos perceber o hibridismo que se instala na estrutura romanesca utilizada pelo autor para assimilar e acomodar essas vozes narrativas que se alternam, inaugurando outra forma romanesca. 


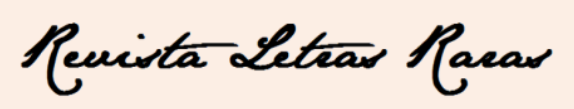

ISSN: 2317-2347 - Vol. 5, Ano 5, № 2 - 2016

Sobre isso, Leite (2012) afirma que

[...] a escolha dos gêneros, no caso do escritor moçambicano Mia Couto, funciona como um filtro, como um modelo interpretativo de realidade da sua sociedade, quer no plano temático, quer no formal, sugerindo-lhe a adoção de certas macroestruturas da forma de expressão, bem como de certos temas ou personagens. Tais escolhas têm como material plástico uma língua que, convém mais uma vez lembrar, foi anteriormente de opressão, mas agora é uma língua liberta e potencialmente híbrida. (LEITE, 2012, p.179)

Nessa perspectiva, as fronteiras genológicas entre textos orais e escritos são implodidas, destruindo um padrão em que cada modalidade está categorizada, inaugurando um registro que hibridiza os domínios do oral e do escrito. O estreitamento da distância entre essas modalidades potencializa a utilização de gêneros característicos da oratura, permitindo a exploração desses novos traços narrativos para a escrita literária.

Peron Rios (2007), ao discutir a questão genológica em Terra sonâmbula, afirma

A pulverização dos gêneros é esse outro campo minado a explorar. Mia Couto trabalha com o que a Teoria Literária moderna denomina gêneros de fronteira, ou seja, aqueles cujos traços limítrofes estão completamente embaçados. De fato, [...] já se observou que seus romances são uma sequência de narrativas menores.

Mia Couto, porém, não deixa apenas os gêneros fora de lugar. A língua, de um modo amplo, é também "desarrumada". Ao mesmo tempo que isso é resultado de um compromisso de todo escritor (pôr a linguagem em seus avessos), não deixa também de ser uma maneira de dar vazão, pela infração expressiva, à inflação do olhar. (RIOS, 2007, p.23)

A linguagem da obra é subversiva pela poética empregada. As imagens são constituídas por conteúdos de uma realidade fragilizada pela destruição da guerra, mas atravessada por um olhar sensível que capta as experiências subjetivas e seus contextos. A profusão poética é arrebatadora por utilizar a palavra para perpassar os cacos da fragmentação das narrativas orais, formulando no enredo um verdadeiro vitral.

\section{Uma travessia pelos enredos das vozes moçambicanas}

A viagem empreendida pelo velho e pelo menino, os inserem na condição de refugiados de guerra que buscam assentamento, acomodação, no entanto, só encontram 


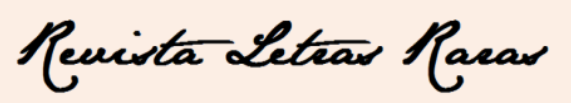

ISSN: 2317-2347 - Vol. 5, Ano 5, № 2 - 2016

experiências humanas que redimensionam a esperança de uma terra de antigos sonhos em uma realidade caótica de uma nação assolada pela destruição.

A estrada que agora se abre a nossos olhos não se entrecruza com outra nenhuma. Está mais deitada que os séculos, suportando sozinha toda a distância. Pelas bermas apodrecem carros incendiados, restos de pilhagem. $\mathrm{Na}$ savana em volta, apenas os embondeiros contemplam o mundo a desflorir.

Um velho e um miúdo vão seguindo pela estrada. Andam bambolentos como se caminhar fosse seu único serviço desde que nasceram. Vão pra lá de nenhuma parte, dando o vindo por não ido, à espera do adiante. (COUTO, 2007, p.9)

Os passos das duas personagens possibilitam o desbravamento dos espaços que são interligados pela estrada. O percurso ganha significação ao desafiar os viajantes que perambulam sem definir um trajeto específico, mas com a esperança de encontrarem refúgio na fuga da guerra. A caminhada se configura como entrecruzamento de diversos outros percursos de outras personagens desoladas em que as experiências humanas se evidenciam e passam a ser os motivos de cada encontro.

O deslocamento das personagens os distancia de uma origem (talvez metáfora do passado), fazendo-os seguir em direção a um destino (talvez metáfora do futuro). Dessa forma, é durante o percurso que os desafios remodelam as identidades. Os encontros com experiências humanas deslocam os sujeitos não só fisicamente, em busca de um lugar desejado, uma espécie de Canaã em solo africano, mas também, movem suas fronteiras subjetivas na ampliação de suas perspectivas frente à modernidade.

Segundo Krakowska (2012), ao estudar as viagens empreendidas nas narrativas africanas, "o movimento da estrada morta pela guerra é um movimento de toda a terra moçambicana que procura recuperar a sua identidade, a sua história, o seu passado e o seu futuro.” (KRAKOWSKA, 2012, p.176-177) A marcha executada por Tuahir e Muidinga é um movimento que interliga os extremos, em que a origem e o destino, o passado e o futuro se interdependem e, dicotomicamente, se unem por um fio condutor, o presente.

Terra sonâmbula se configura como representação de um Moçambique "a desflorir" na condição de pós-independência, vivendo a devastação de uma guerra civil. Nesse contexto, percorrendo caminhos para a sobrevivência em meio à guerra que assola o país, o velho Tuahir e o jovem Muidinga se deparam com diversas experiências que evidenciam o que os dois caminheiros possuem de mais humano: seus sentimentos frente à destruição da guerra, a

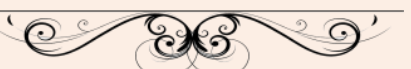




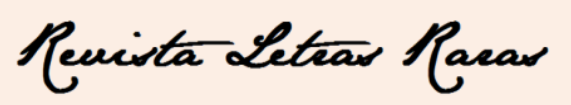

ISSN: 2317-2347 - Vol. 5, Ano 5, № 2 - 2016

esperança que se confunde com ilusão. "Fogem da guerra, dessa guerra que contaminara toda a sua terra. Vão na ilusão de, mais além, haver um refúgio tranquilo.” (COUTO, 2007, p.9)

A viagem como temática da obra é recorrente por representar a experiência de deslocamento do sujeito em busca de uma identidade para suas crenças, para suas ideologias. No entanto, o percurso torna-se meio de inserção desse sujeito numa reflexão profunda sobre si mesmo e sobre sua pertença ao mundo, permitindo uma redefinição na multiplicidade e na fluidez de pensamento da modernidade. A obra moçambicana busca unir as crenças na tradição ao pensamento fluido da modernidade num mesmo instrumento de representação.

Mia Couto, ao ser indagado sobre a viagem como promotora de um processo de autodefinição em uma entrevista, responde:

\begin{abstract}
A viagem nos desloca, nos tira do chão e sem chão a gente tem de repensar, temos de nos repensar a nós próprios, temos que fazer perguntas que nunca pensamos fazer sobre os outros, sobre nós, e como é que os outros são afinal tão parecidos conosco. Acho que ninguém pode ser criativo no sentido de construir um pensamento próprio, pensamento único que é o seu, ter uma voz própria, se não sair de si próprio, sem esta deslocação. Pode ser, a maior parte das vezes tem que ser, a viagem no sentido literal, sair do seu lugar fisicamente, geograficamente e passar a olhar-se de uma outra maneira, mas há outras maneiras de criar esta distância. (COUTO, 2012)
\end{abstract}

Essa trajetória desafiadora inicia um processo de aprendizagem nas personagens que sofrem as influências dos encontros com outros personagens. A cada experiência com Siqueleto, com Nhamataca e até com o aliciamento praticado pelas idosas, por exemplo, ocorre a ampliação da identidade adâmica de Muidinga.

No início do percurso, o machimbombo incendiado torna-se o reduto dos dois que buscam antes um disfarce que o conforto de um lugar aprazível. Mesmo contrariado, o jovem permanece na companhia do velho, tornando-se obediente à tradição que evidencia a sabedoria do mais velho como indicador da iniciação do miúdo na vida adulta. Numa condição adâmica, o jovem aminésico está a se inteirar da vida pelo empirismo das experiências vividas ao lado de Tuahir, das histórias que lhe são contadas pelas vozes da tradição africana, encontradas e encenadas diante de seus olhos, frente às aventuras do jovem Kindzu, retratadas em seus cadernos.

Os primeiros caminhos traçados pelos dois personagens ocorrem na redondeza do machimbombo, quando Muidinga pede a Tuahir para enterrar os corpos carbonizados que 


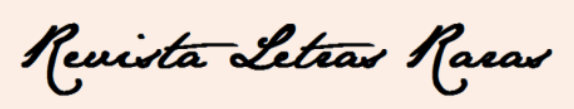

ISSN: 2317-2347 - Vol. 5, Ano 5, № 2 - 2016

encontraram no interior do veículo, por ter medo. A revelação de um corpo com uma mala, encontrado nas imediações por onde sepultam os indigentes, acende a esperança de Tuahir no desejo de haver comida na mala, mas o que encontraram foram cadernos escritos que Muidinga tem o cuidado de recolher e se interessa em ler o que estava escrito naqueles cadernos.

Muidinga nutre zelo, cuidado pelos cadernos como se estivesse a respirar na superfície, antes de morrer afogado no mar do medo que o consome naquele momento. "Muidinga olha o escuro e estremece. [...] Parece todas as sombras desceram à terra. O medo passeia seus chifres no peito do menino que se deita, enroscado como um congolote." (COUTO, 2007. p. 13) O velho deixa escapar a esperança em dias melhores, frente ao choro do menino em meio à destruição. "Qualquer coisa vai acontecer qualquer dia. E essa guerra vai acabar. A estrada já vai-se encher de gente, camiões. Como no tempo de antigamente.” (COUTO, 2007. p. 13) Talvez apenas um desejo de retorno ao passado, à condição colonial como libertação da calamidade instalada ou uma atitude de resiliência que desponta da ressignificação dada ao sofrimento vivido cotidianamente.

Tuahir desconhece sua terra. É estrangeiro em sua nação arrasada pela guerra, por isso, o desejo de retorno à condição colonial. Constituindo-se como símbolo da tradição, o ancião é a personificação dessa tradição que se depara com a modernidade. A juventude impetuosa de Muidinga recebe influência da sábia tradição de Tuahir na formulação de uma identidade subjetiva que finca suas raízes na herança cultural.

Para Krakowska (2012), “a identidade das personagens é construída pela memória" (KRAKOWSKA, 2012, p.180), dessa maneira, Tuahir exerce a extremada relevância por estar inserido na condição de guardião da memória do seu povo e único instrumento da tradição para a iniciação do jovem companheiro. É nesse processo de transmissão de valores que Tuahir e Muidinga configuram o choque entre percepções do mundo, entre passado e presente, entre local e global na configuração de um romance instalado entre fronteiras culturais, temporais e identitárias. "Os mais velhos faziam a ponte entre esses dois mundos." (COUTO, 2007, p.16)

Muidinga se apoia no desejo de sair, de ir além, de descobrir quem são seus pais. A reação do jovem à terra, que dita sonâmbula e que só se move com os sonhos dos homens, que é degradada pela destruição é o que move seus passos. "Se dizia daquela terra que era 


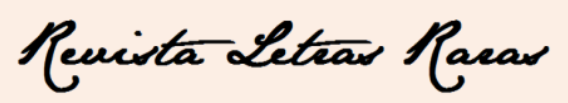

ISSN: 2317-2347 - Vol. 5, Ano 5, № 2 - 2016

sonâmbula. Porque enquanto os homens dormiam, a terra se movia espaços e tempos afora." (COUTO, 2007, s/p) Ao assumir o mesmo percurso, Muidinga une-se a Tuahir por desejar seguir em frente com o desprendimento necessário para a descoberta de novos horizontes, de novas experiências que não aconteçam de forma aleatória, mas que lhe enriqueçam os dias com a sabedoria do mais velho. Os ranhos da convivência entre os dois, paradoxalmente, só aprofundam o laço de confiança, aproxima-os como pai e filho. "O miúdo entorta o nariz, decidido a desobedecer." (COUTO, 2007, p.36)

O compartilhamento dos percursos da caminhada passa a ressignificar cada passo do trajeto percorrido por eles. A convivência entre o velho e o miúdo os aproxima, torna-os resistentes ao ambiente desfavorável que os rodeia. O caminhar só tem sentido se os dois estiverem juntos. O périplo é apenas um subterfúgio para a permuta de experiências humanas e subjetivas que, naquele contexto, se singularizam e ganham matéria para o distanciamento da solidão e da desesperança causadas pelas consequências da guerra.

A descoberta dos cadernos de Kindzu e a significação a eles atribuída pelo jovem, insere a caminhada dos dois viajantes numa experiência profunda entre subjetividades atravessadas por perspectivas distintas do mundo. A leitura dos cadernos passa a remodelar o destino de Muidinga que se depara com as experiências de Kindzu frente ao desejo de se tornar um naparama.

Como já mencionado, Muidinga e Tuahir são símbolos dos enfrentamentos entre a tradição e a modernidade numa Moçambique que divaga em busca de um projeto de nação, de uma identidade que deve ser reconstruída após a destruição. Sobre isso, Krakowska (2012) afirma que "as andanças da terra e dos seus habitantes podem ser vistas como viagens na busca da ideia de nação perdida." (KRAKOWSKA, 2012, p.177) Dessa forma, os percursos (sejam físicos ou literários) dos dois personagens ocorrem como meios de busca por uma ideia de nação a ser (re)construída.

O miúdo, a partir da leitura dos cadernos de Kindzu, se depara com dois caminhos que se formulam à sua frente através das experiências vividas ao lado do velho e dos relatos das experiências de Kindzu. Além disso, o rapaz busca uma identidade individual por não lembrar-se de seu passado, desejando assumir, por vezes, as diversas identidades que se apresentam nas histórias dos cadernos. 


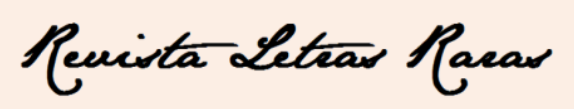

ISSN: 2317-2347 - Vol. 5, Ano 5, № 2 - 2016

O devaneio nos mitos, nos sonhos, na fantasia proporcionada pelos próprios cadernos e nas experiências vividas na viagem ao lado de Tuahir constitui-se como experiências de leitura que, de certo modo, incidem na configuração da subjetividade de Muidinga. O desejo de encontrar-se passa a emanar das reflexões do personagem frente à leitura dos cadernos, ressignificando a própria existência desafiada pela ausência da memória e pelas consequências da guerra que tanto o angustia.

O dia já se ergueu, as sombras vão minguando na quentura do chão. O sol, voluminoso, sucessivamente sempre sendo um. Muidinga imagina como será uma aldeia, essas de antigamente, cheinhas de tonalidades. As colorações que devia haver na vila de Kindzu antes da guerra desbotar as esperanças?! Quando é que cores voltariam a florir, a terra arco-iriscando?

Então ele com um pequeno pau rabisca na poeira do chão: “AZUL”. Fica a olhar o desenho, com a cabeça inclinada sobre o ombro. Afinal, ele também sabia escrever? Averiguou as mãos quase com medo. Que pessoa estava em si e lhe ia chegando com o tempo? Esse outro gostaria dele? Chamar-se-ia Muidinga? Ou teria outro nome, desses assimilados, de usar em documento? (COUTO, 2007, p.37)

A condição de leitor dos cadernos proporciona ao menino o contato com os desejos de Kindzu em concretizar seu grande objetivo. A inscrição da leitura dos cadernos em Muidinga constata a dimensão de sentido que esta passa a exercer na identificação entre os sujeitos que nela se implicam. Desse processo ocorre a ampliação do conceito da leitura que não comporta apenas a identificação do código linguístico utilizado, mas a implicação das experiências subjetivas como meio de compartilhamento existencial. É por essa identificação que Muidinga também se depara com seu desejo de encontrar os pais, indefinindo a fronteira dos próprios desejos que se misturam aos desejos de Kindzu.

Nesse sentido, a palavra é fronteira entre a noção de realidade e a fantasia. É por meio das escrituras que as experiências culturais se delineiam, fundando e reformulando as relações entre a tradição e a modernidade. A imbricação entre tais aspectos fica evidente na consideração das culturas africanas enraizadas em uma mitologia local, nos ensinamentos veiculados em narrativas orais, herdadas dos antepassados, e na crença religiosa que se configura a partir da comunicação entre os vivos e os mortos com interferências diretas nos fatos da realidade.

Em Terra sonâmbula, a experiência de leitura dos cadernos de Kindzu está profundamente arraigada ao desejo de considerar o passado na formulação da condição póscolonial. Dessa maneira, as personagens passam a reconhecer a escrita como parte do 


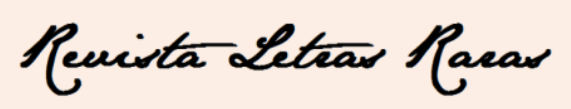

ISSN: 2317-2347 - Vol. 5, Ano 5, № 2 - 2016

imaginário mitológico, até então, exclusivamente repassada pela herança cultural da oralidade. As palavras oral e escrita se imbricam, reinventando novos espaços na difusão da polifonia das culturas africanas, constituídas pelas experiências subjetivas.

A leitura dos cadernos de Kindzu insere Muidinga numa experiência sinestésica que aproxima o âmbito do real com a fantasia. "O jovem passa a mão no caderno, como se palpasse as letras." (COUTO, 2007, p.34) Dessa proximidade, ocorre a configuração da palavra como lugar da ambivalência das dimensões do real, do palpável e da fantasia, da imaginação. A leitura implode as desesperanças e as destruições da realidade caótica da guerra, inaugurando, mesmo que por instantes, um mundo em que apenas o sujeito-leitor está inserido em suas certezas e encantamentos.

O miúdo lê em voz alta. Seus olhos se abrem mais que a voz que, lenta e cuidadosa, vai decifrando as letras. Ler era coisa que ele apenas agora se recordava saber. O velho Tuahir, ignorante das letras, não lhe despertara a faculdade da leitura.

A lua parece ter sido chamada pela voz de Muidinga. A noite toda se vai enluarando. Pratinhada, a estrada escuta a estória que desponta dos cadernos: "Quero pôr os tempos..." (COUTO, 2007, p.14)

Por esse prisma, a palavra oral ou escrita ganha valoração. Muidinga e Tuahir são envolvidos pela dimensão que os escritos de Kindzu ganham ao inscreverem a subjetividade de quem traçou os mesmos caminhos que eles percorrem. Os significados dos cadernos desviam o sofrimento diário do périplo dos caminheiros, reconduzindo-os para um mundo paralelo em que a realidade é a mesma, entretanto, com contornos de aventura de um herói nacional.

Terra sonâmbula é um romance constituído por essas duas histórias paralelas que se fundem numa grande viagem a um Moçambique desolado e sem perspectiva de criação de uma identidade nacional que ganha forma nos mitos e nas histórias de seus habitantes.

É a palavra que permite a implicação dos sujeitos no compartilhamento dos significados das experiências subjetivas. Dessa maneira, a palavra ganha uma dimensão catártica em que resguarda os sujeitos no compartilhamento das angústias, tornando-se instrumento para a inserção do enunciador e do leitor/expectador num estado de amenização das dores consubstanciadas com a realidade. 


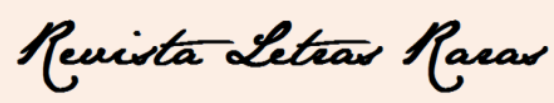

ISSN: 2317-2347 - Vol. 5, Ano 5, № 2 - 2016

Tuahir havia entendido: os escritos de Kindzu traziam ao jovem uma memória emprestada sobre esses impossíveis dias. Ao menos ele acreditasse tudo aquilo ser fantasia, estoriazinha que se conta para fazer de conta.

- Sabe, miúdo, o que vamos fazer? Você me vai ler mais desses escritos.

- Mas ler agora, com esse escuro?

- Acendes o fogo lá fora.

- Mas, com a chuva a lenha toda se molhou.

- Então vamos acender o fogo dentro do machimbombo. Juntamos coisa de arder lá mesmo.

- Podemos, tio? Não há problema?

- Problema é deixar este escuro entrar na cabeça da gente. Não podemos dançar nem rir. Então vamos para dentro desses cadernos. Lá podemos cantar, divertir. (COUTO, 2007, p.126)

O ato de narrar é marca cultural em que se dá voz aos silêncios que reverenciam a dominação das mudanças trazidas pela modernidade. $\mathrm{O}$ valor da palavra escrita é uma dessas mudanças que interfere substancialmente nas culturas africanas. No entanto, a experiência narrativa oral acende nas personagens a condição de criadores, de enunciadores das vozes culturais que buscam a permanência frente à dominação da cultura escrita.

Nesse sentido, a atitude de narrar se espalha pela maioria das personagens, que como griots, assumem a postura de reprodutores performáticos das vozes africanas da tradição. No âmbito genológico, o romance em estudo assimila e acomoda essas narrativas orais nos enredos que compõem a construção dos personagens, inaugurando uma narrativa multifacetada, aproximando-a da contação feita por Sherazade nas Mil e uma noites.

No âmbito intradiegético, o aspecto estético e o encantamento em que cada narrativa está enraizada permite a percepção de uma função bárdica das leituras feitas por Muidinga, que se coloca na condição de um griot, na contação dos enredos dos escritos de Kindzu. Sobre isso, Ana Mafalda Leite (2012) afirma

A tradição, representada pelo mundo dos mais velhos, é assumida pelos mais novos através da leitura e da escrita, recriando-a estes através da vocalização da letra. A representação do ato de narrar expande-se, em espelho, em cada uma das narrativas. Cada um dos narradores dá voz a outros narradores secundários; todos querem contar estórias, Taímo, Tuahir, Farida, Quintino, Virgínia, Euzinha, o pastor, Nhamataca, Siqueleto.

A teatralização da voz pela escrita, encenada pela leitura em voz alta, vem reabilitar o diálogo entre o narrador e o ouvinte, característico da execução oral, e adequar a função bárdica aos tempos modernos, representando-a como um sistema comunicativo socializado, que mantém a cumplicidade entre o contador e o público. (LEITE, 2012, p.180-181) 


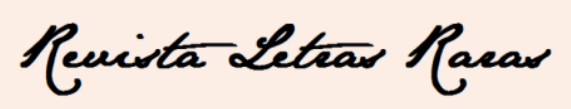

ISSN: 2317-2347 - Vol. 5, Ano 5, № 2 - 2016

A subversão das fronteiras entre oralidade e escrita reconfigura a leitura que não só influi subjetivamente, mas coletivamente ao se oralizarem as palavras dos cadernos. A palavra mítica não só encanta como assegura ao leitor/ouvinte um portal para a fantasia, para o distanciamento da realidade que a cerca, permitindo um esvaziamento das angústias subjetivas.

A leitura dos cadernos por Muidinga em voz alta para Tuahir, desperta uma referência à contação de histórias míticas ao redor da fogueira, como um costume de povos ágrafos que há séculos deixam seu imaginário como herança cultural para seus descendentes. Nesse sentido, a palavra oralizada tem um valor performático que ressalta a significação das narrativas orais.

Esse mergulho na fantasia pelo menino e pelo velho é um processo em que a leitura tem a capacidade de desvincular o sujeito da realidade que o cerca, "não deixa o escuro entrar na cabeça da gente." (COUTO, 2007, p.126), fazendo-nos “cantar, divertir" longe da realidade.

Mia Couto fala sobre essa missão catártica que o texto literário exerce num contexto de formação de uma ideia de nação. O autor afirma que

A escrita literária pode levantar porque se percebe que está a tratar isso como uma história; como uma história, digamos assim, procurando não apontar dedos ou culpas. E por isso a escrita pode ter este efeito curativo, não é? Uma espécie de catarse, que é importante ser feita. (COUTO, 2012, p.165)

Em toda parte, Kindzu encontra motivos para a contação de histórias que amalgamadas às experiências vividas por Muidinga criam no menino/leitor uma memória recente sobre sua condição frente ao caos, permitindo-lhe uma amenização de sua angústia amnésica. A leitura ganha significação nesse processo de repatriação de Muidinga nessa nação sem fronteiras. Sua vinculação à nova identidade ocorre, inicialmente, pelos mitos, pelas crendices e é viabilizada pelas narrativas de Kindzu que o conduz por uma viagem heroica sinuosa que culmina na realização do desejo de ser um naparama.

A palavra é matéria-prima para a formulação de uma nova perspectiva da nação. A inserção da escrita em meio à cultura oral indica o domínio das culturas estrangeiras que se digladiam com a tradição em busca de espaço na cultura local. Todavia, a escrita passa a ser 


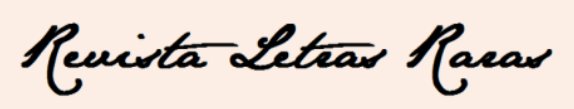

ISSN: 2317-2347 - Vol. 5, Ano 5, № 2 - 2016

formulada pela polifonia oral africana, ganhando novas feições na estrutura, na linguagem e no conteúdo.

Nesta perspectiva, Peron Rios (2007) em seu estudo sobre Terra sonâmbula afirma que

\begin{abstract}
Narrar é desfiar esse rosário, ato religioso, onde fragmentos se religam. Todo texto é comunhão, explícita ou velada, de orações - reza a gramática. A escrita de Mia Couto, dada a profusão de imagens que ali se bordam, traz uma apresentação barroca. O que não figura inteiramente estranho, tendo em vista a filiação roseana de sua prosa. Algo se erotiza não ao revelar sua imediata nudez, mas ao deixar-se vislumbrar pelo buraco da fechadura. A palavra surge como um fio que se desprendeu e pelo qual se puxa, reduzindo as vestimentas às mínimas partes. Atitude inegavelmente erotizante, narrar é tecer o gozo através de uma lenta e gradual nudez das coisas. Numa conciliação entre o erotismo e a liturgia, o narrador também é capaz de "amenizar" o universo, como um curandeiro. (RIOS, 2007, p.84)
\end{abstract}

As escuridões subjetivas são clareadas pela luminosidade das narrativas que ganham vida pela voz dos narradores. As palavras são antídotos degustados pelos enunciadores. Cada palavra que emana do sujeito está carregada das subjetividades, das angústias íntimas, fornecendo alívio na carga semântica que carrega. Dessa maneira, o ato de narrar insere o locutor e expectador nas dobras de uma narrativa movedora do solo da realidade numa viagem à fantasia.

As diversas narrativas orais do romance são unidas pela leitura de Muidinga. Nesse sentido, as particularidades dos contos orais permanecem (o núcleo narrativo, o desfecho surpreendente, por exemplo) e, ao mesmo tempo, estão atravessadas pela escrita que evidencia a linguagem, transformada em um objeto iluminador das tramas narrativas.

O romance, nesse processo de reconfiguração, se abre para a assimilação dessa multiplicidade de narrativas. As novas feições do gênero formam um mosaico de fragmentos que constituem uma unidade. Os enredos se interpenetram, fundindo-se em uma multiplicidade de aspectos que movem as certezas em novos padrões, a inauguração de mais uma cultura do romance.

\title{
4 Considerações finais
}




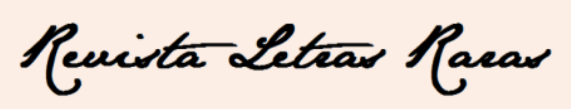

ISSN: 2317-2347 - Vol. 5, Ano 5, № 2 - 2016

As especificidades reveladas pelos estudos das obras africanas de Língua Portuguesa, nomeadamente ao nos debruçarmos sobre a obra Terra sonâmbula, de Mia Couto, nos insere na percepção da relevância das produções dos autores africanos contemporâneos que inscrevem essas vozes por muito tempo silenciadas e inauguram formas literárias que revelam suas particularidades culturais.

As marcas da textualidade africana estão vinculadas às expressões culturais em que as tradições orais se fundem ao surgimento da escrita. A linguagem é esse campo que inscreve as imbricações entre a oralidade e a escrita, ganhando contornos performáticos para estabelecer relações com as heranças culturais de seus povos.

Nesse sentido, a percepção da palavra escrita e a consideração de suas dimensões estéticas apontam para a formulação cultural que particulariza a própria linguagem literária e move os limites entre a oratura e a escrita. O signo/A palavra ganha potência e se corporifica no texto de onde se emana as vozes narrativas cultivadas pelo imaginário local que se torna universal pela força do texto literário.

Terra sonâmbula acomoda, em sua construção binária de enredos entremeados por pequenas narrativas que formam uma grande teia, o "arquienredo" do romance. Essa forma narrativa híbrida reúne aspectos da tradição africana associando-os à palavra escrita que atribui voz aos personagens que existem enquanto contam suas histórias.

A presença da literatura africana de Língua Portuguesa, como objeto de estudo nas aulas de literatura do nosso país, constitui-se em um passo importante para a difusão da experiência de consideração da diversidade cultural, da superação da visão colonialista, abordando obras que difundem valores culturais de além-mar.

\section{REFERÊNCIAS}

AGUIAR E SILVA, V. M. Teoria da literatura. 8.ed. Coimbra: Almedina, 2011.

BHABHA, H. K. O local da cultura. Trad. Myriam Ávilla, Eliana Lourenço, Gláucia Renate. 2.ed. Belo Horizonte: Editora da UFMG, 2013.

COUTO, M. Terra sonâmbula. São Paulo: Companhia das Letras, 2007. O outro pé da sereia. São Paulo: Companhia das Letras, 2006.

HALL, S. A identidade cultural na pós-modernidade. Rio de Janeiro: Lamparina, 2014. 


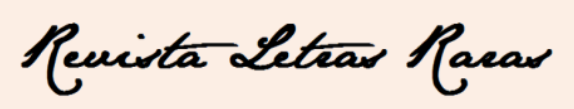

ISSN: 2317-2347 - Vol. 5, Ano 5, № 2 - 2016

Da diáspora: identidades e mediações culturais. Trad. Adelaine Resende. 2.ed. Belo Horizonte: Editora UFMG, 2013.

LEITE, Ana Mafalda. Literaturas africanas e formulações pós-coloniais. 2.ed. Lisboa: Colibri, 2013.

. Oralidades \& escritas pós-coloniais: estudos sobre literaturas africanas. Rio de Janeiro: EdUERJ, 2012.

OWEN, H; CHAVES, R; APA, L. (Orgs.) Nação e narrativa pós-colonial I: Angola e Moçambique. 1.v.: Ensaios. Lisboa: Colibri, 2012.

. KHAN, S; FALCONI, J; KRAKOWSKA, K. (Orgs.) Nação e narrativa pós-colonial II: Angola e Moçambique. 2.v.: Entrevistas. Lisboa: Colibri, 2012.

RIOS, Peron. A viagem infinita: estudos sobre Terra sonâmbula de Mia Couto. Recife: EDUFPE, 2007.

ZUMTHOR, P. Performance, recepção, leitura. Trad. Jerusa Pires e Suely Fenerich. São Paulo: Cosac Naify, 2014.

Recebido em: 30/09/2016

Aceito em: 12/11/2016 